\title{
The Rural Origins of the Communist and Nationalist Movements in Wolyn Województwo, 1921-1939
}

When two diametrically opposed revolutionary movements gain the support of the peasantry of a given population, it is logical to ask whether this support came from all peasant strata equally or from one in particular. This question is especially relevant to the eastern Polish województwo of Wolyn in the 1930s. Overwhelmingly populated by Ukrainian peasants, the rural areas of Wolyn wojezództwo were strongly influenced by both Ukrainian Communists (represented by the Communist Party of Western Ukraine, Komunistychna Partiia Zakhidnoi Ukrainy, or KPZU) ${ }^{1}$ and Ukrainian Nationalists (represented by the Organization of Ukrainian Nationalists, Orhanizatsiia Ukrains'kykh Natsionalistiv, or OUN.$^{2}$ Both organizations offered radical solutions to the socioeconomic and nationality problems facing the Ukrainian peasantry, and both received the support of large segments of the peasantry. But which particular segments supported which movement?

This question has been largely overlooked in the literature dealing with the KPZU and the OUN. Ukrainian students of the period-Nationalists as well as Communists - tend to make vague and generally unscholarly claims that their side enjoyed the unswerving support of the "popular masses." ${ }^{3}$ Western scholars,

1. Scholarly works on the KPZU are scarce. The most noteworthy include: Janusz Radziejowski, Komunistyczna Partia Zachodniej Ukrainy 1919-1929: Wezlowe problemy ideologiczne (Cracow, 1976) ; Ie. M. Halushko, Narysy istorii KPZU 1919-1928 rr. (Lwów, $1965)$; O. Karpenko, "Do pytannia pro vynyknennia i orhanizatsiine oformlennia Kommunistychnoi Partii Skhidnoi Halychyny," in $Z$ istorii zakhidnoukrains'kykh zemel', vol. 2 (Kiev, 1957) ; Roman Solchanyk, "The Foundation of the Communist Movement in Eastern Galicia 1919-1921," in Slavic Review, 30, no. 4 (December 1971) : 774-94; A. D. Iaroshenko, Komunistychna partiia Zakhidnoi Ukrainy-Orhanizator $i$ kerivnyk revoliutsiinoi borot'by trudiashchykh zakhidnoukrains'kykh zemel' (Kiev, 1959). The following works deal with the KPZU's role in Wołyń województze: Borot'ba trudiashchykh Volyni za vozziednannia $z$ radians'koiu Ukrainoin (1929-1939 rr.), vol. 2 (Lwów, 1965); M. M. Kravets', "Revoliutsiinyi rukh na Volyni v period svitovoi ekonomichnoi kryzy v 1929-1933 rr.," in $Z$ istorii zakhidnoukrains'kykh zemel', vol. 3 (Kiev, 1958) ; I. K. Vasiuta, Selians'kyi rukh na Zakhidnii Ukraini 1919-1939 rr. (Lwów, 1971); I. Zabolotnyi, Neskorena Volyn' (Lwów, 1964); M. I. Zil'berman, Revoliutsiina borot'ba trudiashchykh Zakhidnoi Ukrainy 1924-1928 rr. (Lwów, 1968).

2. Much has been written about the OUN and the nationalist movement in general; very little, however, is of value to the scholar, except for: John Armstrong, Ukrainian Nationalism, 2nd ed. (New York, 1963); Roman Ilnytzkyj, Deutschland und die Ukraine 1934-1945 (Munich, 1955); Ryszard Torzecki, Kwestia ukrainska w polityce III Rzeszy 1933-1945 (Warsaw, 1972) ; Lev Rebet, Svitla i tini OUN (Munich, 1964); Petro Mirchuk, Narys istorii Orhanizatsii Ukrains'kykh Natsionalistiv 1920-1939 (Munich, 1968); Volodymyr Martynets', Ukrains'ke pidpillia vid UVO do OUN (West Germany, 1949) ; Orhanizatsiia Ukrains'kykh Natsionalistiv 1929-1954 (Paris, 1955); OUN v svitli postanov Velykykh Zboriv, Konferentsii ta inshykh dokumentiv z borot'by 1929-1955 (Munich, 1955).

3. Mirchuk provides a good example of this tendency: "The intensified revolutionary activity of the OUN was surprisingly fast in liquidating the heretofore fairly strong influence 
on the other hand, have yet to confront the problem. ${ }^{4}$ In any case, an appropriate theoretical apparatus, one that involves a detailed analysis of concrete aspects of the peasantry's social structure, is necessary in order to reach a satisfactory answer.

Roy Hofheinz and Eugen Weber have made provocative attempts to locate sources of the rural strength of radical political movements by means of highly suggestive correlation analyses. ${ }^{5}$ Although Hofheinz deals with the Chinese Communists and Weber with the Rumanian Iron Guard, both scholars employ essentially the same technique: after determining where the radical movement was strongest, they search for social conditions more or less peculiar to the area of the movement's strength on the assumption that peculiarity implies some degree of causality. The present analysis is theoretically and technically similar to Hofheinz's and Weber's analyses, but its focus is on one very specific and statistically quantifiable factor-landholdings. Do landlessness or the size of a peasant's landholding play some role in determining the peasant's political predilections? That this is so is pretty much taken as an axiom of current social science research on this question. Jeffrey Paige has pointed out that a peasant's relationship to the land he works is very closely related to the form his political activity will take. ${ }^{6}$

Naturally, no one factor can ever suffice to explain a social phenomenon, and landholdings alone obviously do not "explain" Ukrainian Communist and Ukrainian Nationalist influence in Wołyn województwo. The size of the working class, the extent of urbanization, a region's geopolitical significance, as well as such cultural factors as religion, education, and ideology are also of great significance. However, insofar as the problem being examined is the radical movements' relationship to the peasantry, land-that which makes the peasant uniquely a peasant-assumes particular importance.

It is often assumed that a movement of the radical left, such as the KPZU, draws its support from the lowest classes and strata of a given population, and

of the Communists and consolidated the influence of Ukrainian nationalism among the broadest Ukrainian masses" (see Mirchuk, Narys istorii Orhanizatsii Ukrains'kykh Natsionalistiv, p. 454). Vasiuta is typical of the opposite tendency: "The great ideas of Marxism-Leninism lighted the path of the revolutionary movement in Western Ukraine. Under the leadership of the KPZU this movement developed on the principles of class solidarity and proletarian internationalism. On the basis of the experience of the CPSU and its component part, the CP Ukraine, the Communists of Western Ukraine mastered the legal and illegal forms of struggle and spread their influence over the toiling masses of the village" (see Vasiuta, Selians'kyi rukh, pp. 62-63).

4. John Armstrong, the only non-Ukrainian Western scholar to have studied Ukrainian nationalism, deals only with the political and ideological aspects of the movement (see Armstrong, Ukrainian Nationalism).

5. Roy Hofheinz, "The Ecology of Chinese Communist Success: Rural Influence Patterns, 1923-1943," in A. D. Barnett, ed., Chinese Communist Politics in Action (Seattle: University of Washington Press, 1969), pp. 3-77; Eugen Weber, "The Men of the Archangel," in Walter Laqueur and George L. Mosse, eds., International Fascism 1920-1945 (New York: Harper \& Row, 1966), pp. 101-26.

6. Jeffrey Paige, Agrarian Revolution: Social Movements and Export Agriculture in the Underdeveloped World (New York: The Free Press, 1975). Some of the more recent literature dealing with this theme includes Joel Migdal, Peasants, Politics and Revolution (Princeton, 1975); Comparative Politics, 8, no. 3 (April 1976) (special issue on "Peasants and Revolution"); James C. Scott, "Exploitation in Rural Class Relations: A Victim's Perspective," Comparative Politics, 7, no. 4 (July 1975). 
that a movement of the radical right, such as the OUN, finds its supporters among the middle or lower middle classes. One might therefore-expect the landless agricultural laborers and poor peasants (defined as owning 0-5 hectares of land) to support the Communists, and the middle (5-10 hectares) and rich (10-50 hectares) peasantry to support the Nationalists. This study, however, will show that the reality of radical agrarian politics in Wolyn zojewództwo in the 1930 s was far more complex.

Although agricultural laborers were indeed the backbone of the KPZU in the countryside, poor peasants rallied not to the Communists, but to the Nationalists. On the other hand, neither the rich nor the middle peasantry apparently saw the OUN as representing their interests. In short, the rural poor, as represented by two very different strata, served as the base for both revolutionary movements. An explanation of why the peasantry aligned itself in this manner will be offered after the empirical data are presented.

Wołyń, along with Lwów, Tarnopol, and Stanisławów, was one of four województwa in interwar Poland where Ukrainians comprised the majority of the population. Located in the southeastern corner of the newly founded state, Wołyń województwo consisted of nine-eleven administrative districts known as porriaty between 1921 and 1939. The 1921 census lists Dubno, Horochów, Kowel, Krzemieniec, Luboml, Łuck, Równe, Włodzimierz, and Ostróg (named after their administrative centers). By the $1930 \mathrm{~s}$, the boundaries of most of these powriaty had been changed, sometimes radically: the powrat of Ostróg was renamed Zdołbunów, that of Równe was divided into Równe and Kostopol powiaty, and an eleventh powiat, Sarny, was detached from Polesie województwo in the north and added to Wołyn.

Wołyń województwo was one of Poland's most underdeveloped regions. Large areas were covered with dense forests and much of the available agricultural land was of poor quality. Industry was virtually nonexistent and basic commodity consumption was much lower than in other województwa. The majority of the Greek Orthodox Ukrainian population was illiterate and lacking in national self-awareness.

Wolyn's total population at the time of the 1931 census was 2,085,574. Ukrainians comprised about 68 percent of this number, Poles 17 percent, and Jews 8 percent. The remainder was divided among Russians, Belorussians, Czechs, Lithuanians, and Germans. ${ }^{7}$ About 95 percent of all Ukrainians in Wołyn lived in villages. Those inhabiting the cities were a small minority compared to the numerically dominant urban ethnic groups-the Poles and Jews. It is not surprising that most Ukrainians were involved in some form of agriculture. As the censuses of 1921 and 1931 reveal, 93 percent of all Ukrainians worked in agriculture, and only 3 percent in mining and industry. The remaining 4 percent were fairly equally divided among commerce, communications and transport, public service, domestic service, and officially registered unemployment. ${ }^{8}$ With regard to rural Ukrainians alone, 96 percent were occupied in agriculture, with only 2 percent in mining and industry. ${ }^{9}$ The Ukrainian working

7. Drugi powszechny spis ludności $z$ dn. $9 . X I I 1931$ r., Województwo Wolyniskie (Warsaw, 1938), pp. 28-29.

8. Ibid., pp. 297-326.

9. Le premier recensement général de la République Polonaise du 30 septembre 1921, Départment de Wotyń (Warsaw, 1926), pp. 181-85. 
Table 1. Ratio of Number of Ukrainians to Number of Communists, Wolyń Województwo, 1931

\begin{tabular}{|c|c|c|c|}
\hline Powiat & $\begin{array}{c}\text { (1) } \\
\text { Total } \\
\text { Ukrainian } \\
\text { Population }\end{array}$ & $\begin{array}{c}\text { Total } \\
\text { Combined KPZU-Komsomol } \\
\text { Membership }\end{array}$ & $\begin{array}{c}\text { (3) } \\
\text { Ratio } \\
(1) \div(2)\end{array}$ \\
\hline Kowel & 185,240 & 602 & 308: 1 \\
\hline Euck & 172,038 & 303 & 568: 1 \\
\hline Luboml & 65,906 & 80 & 824: 1 \\
\hline Horochów & 84,224 & 98 & $859: 1$ \\
\hline Whodzimierz & 88,174 & 32 & $2,755: 1$ \\
\hline Dubno & 158,173 & 56 & $2,825: 1$ \\
\hline Sarny & 129,637 & 41 & 3,162: 1 \\
\hline Zdołbunów & 81,650 & 23 & $3,550: 1$ \\
\hline Kostopol & 105,346 & 29 & $3,632: 1$ \\
\hline Krzemieniec & 196,000 & 31 & $6,323: 1$ \\
\hline Równe & 160,484 & 17 & $9,440: 1$ \\
\hline
\end{tabular}

Sources: Drugi powszechny spis ludności z dn. $9 . X I I 1931$ r., Województwo Wolyńskie (Warsaw, 1938), pp. 28-29; Borot'ba trudiashchykh Volyni za vozziednamnia z radians'koiu Ukrainoiu (1929-1939 rr.), vol. 2 (Lwów, 1965), p. 123.

class, meanwhile, although not an insubstantial number (some eleven to twelve thousand), was not sufficiently large to provide the base for any political group seeking influence among the Ukrainian population. ${ }^{10}$

With its already severe socioeconomic problems further aggravated by the Depression, Wołyń offered ideal conditions for rural revolutionary agitation by Communists and Nationalists. Communist influence was strongest in Wołyń województwo in the $1920 \mathrm{~s}$ and progressively declined thereafter. Nationalism asserted itself in the middle of the 1930 s and remained virtually unchallenged throughout the early 1940s.

Ukrainian Communists were organized within the Communist Party of Western Ukraine (known as the Communist Party of Eastern Galicia until 1923). Because the KPZU was illegal, Ukrainian Communists often worked through such legal front organizations as the Ukrainian Peasants' and Workers' Socialist Union $\left(S e l^{\prime}-R o b\right)$. Troubled by ideological conflicts usually involving some aspect of the nationality question and its proper implementation in the Ukrainian województwa of Poland, the KPZU underwent frequent crises culminating in a damaging schism in 1928. On the wane during the 1930s, the KPZU as a component part of the Communist Party of Poland was dissolved in 1938 by the Comintern.

To find the powiaty where the KPZU was relatively strong, the relationship between the size of a powiat's total Ukrainian population and the size of that pozerat's combined KPZU-Komsomol membership must be examined (see table 1). The porriaty of relatively greatest Communist strength may be determined in this manner, because cadre size alone is obviously insufficient for comparative purposes. On the reasoning that the smaller the ratio of Ukrainians to Communists, the greater the relative KPZU strength, it is clear that Kowel, Luck, Luboml, and Horochów were the pozeraty with the relatively largest Ukrainian Communist presence.

10. Ibid., p. 168. 
Table 2. Ratio of Number of Ukrainians to Number of Arrested Nationalists, Wotyń Woiewództwo

\begin{tabular}{lccc}
\hline & $\begin{array}{c}(1) \\
\text { Total } \\
\text { Ukrainian } \\
\text { Population, 1931 }\end{array}$ & $\begin{array}{c}(2) \\
\text { Number of Arrested } \\
\text { OUN Members, } \\
1934-38\end{array}$ & $\begin{array}{c}(3) \\
\text { Ratio } \\
(1) \div(2)\end{array}$ \\
\hline Euck & 172,038 & 133 & $1,294: 1$ \\
Kostopol & 105,346 & 68 & $1,549: 1$ \\
Krzemieniec & 196,000 & 47 & $4,170: 1$ \\
Równe & 160,484 & 33 & $4,863: 1$ \\
Włodzimierz & 88,174 & 16 & $5,511: 1$ \\
Horochów & 84,224 & 9 & $9,358: 1$ \\
Dubno & 158,173 & 13 & $12,167: 1$ \\
Zdołbunów & 81,650 & 5 & $16,330: 1$ \\
Kowel & 185,240 & 8 & $23,155: 1$ \\
Luboml & 65,906 & $\mathrm{a}$ & \\
Sarny & 129,637 & $\mathrm{a}$ & \\
\hline
\end{tabular}

a Data unavailable.

Source: Petro Mirchuk, Narys istorii Orhanizatsii Ukrains'kykh Natsionalistiv 1920-1939 (Munich, 1968), pp. 389-480.

Ukrainian Nationalists belonged to the OUN, a "supraparty" movement founded in Vienna in 1929. Demanding an independent Ukrainian state and a thoroughgoing social revolution, the OUN based its agrarian program on the preservation of private landholdings and the formation of a strong, landed peasantry. Initially consisting almost entirely of urban-based students, its cadres in time came to include large segments of the rural Ukrainian population as well. Even so, the young remained in the majority throughout the existence of the illegal organization. The OUN was originally confined to the Ukrainian wojewodztwa of eastern Galicia, but in the $1930 \mathrm{~s}$ it initiated serious efforts to infiltrate Wolyn and, in the process, the organization developed a large indigenous network that was modeled on the Galician pattern.

Attempting to determine relative OUN strength in Wołyn województwo, however, is a problematic undertaking because no organized statistics such as those for the KPZU exist. The method employed here involved checking lists of Nationalists arrested between 1934 and 1938 (compiled on the basis of newspaper accounts which are necessarily incomplete) and determining the powiaty of their origin. This approach is obviously schematic but can suggest the areas of the organization's relative influence. Table 2 provides the numbers of arrested OUN members and the ratios of Ukrainians to arrested Nationalists. The ratios clearly suggest that the pozriaty of Luck, Kostopol, Krzemieniec, and Równe may be considered Nationalist strongholds. Significantly, this conclusion is borne out in interviews with former members of the OUN in Wolyn. According to these participants, however, the Zdołbunow powiat was also strongly influenced by Nationalists. ${ }^{11}$

A comparison of Nationalist powiaty with Communist powiaty reveals that the strength of the KPZU lay in the western part and that of the OUN in the

11. Interviews with formerly prominent Nationalists who prefer anonymity. 
Figure 1. Pozviaty of Relative KPZU and OUN Strength, Wolyń Wojezwództwo, circa 1930

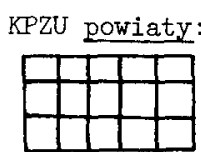

OUN powiaty:

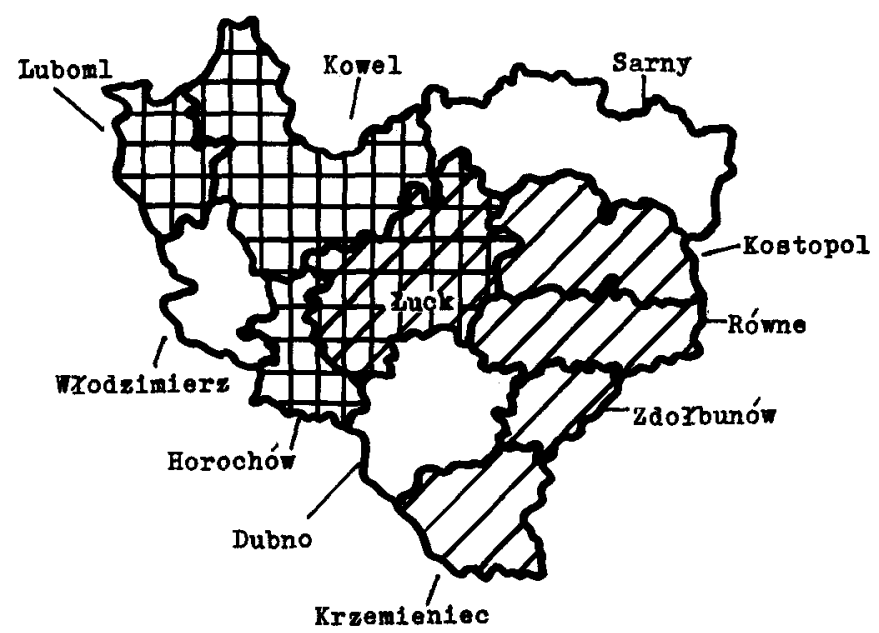

eastern part of the województwo. Influence in Luck powiat appears to have been more or less equally shared by Nationalists and Communists. These spheres of influence are illustrated in figure 1 .

How then do these findings relate to the social structure of the Ukrainian countryside? A crucial factor for understanding the importance of land to the social reality of Wołyń województwo is the Polish government's interwar policy of "colonizing" its so-called "eastern borderlands" (kresy wschodnie) with Polish settlers from the interior of the country. Such colonization was particularly intensive in Wołyn, where there was a large supply of formerly Russian imperial or landowner property that could be distributed or "parceled" out. Throughout the interwar decades colonization and land apportionment went hand in hand as part of the government's land reform. The indigenous Ukrainian peasantry, however, was largely overlooked in this regard, with most of the parceled land going to newly arrived Polish colonists.

The Ukrainian peasant's already severe land hunger was further aggravated by a 47 percent increase in the rural Ukrainian population between 1921 and 1931 -from 938,052 to $1,385,867.12$ At the same time, the number of urban Ukrainians declined from 45,544 in 1921 to 41,005 in 1931 -a 9 percent decrease. ${ }^{13}$ Extreme overpopulation in rural areas and land hunger combined to make a potent issue for both Communists and Nationalists.

Statistics for landholdings by nationality exist only in the 1931 census. These are grouped into two categories: those owners who "employ hired labor" and those who do not. The latter were independently owned farms and constituted 95-98 percent of all Ukrainian landholdings, depending on the pozriat.

12. Compiled on the basis of Le premier recensement général, p. 63; and Drugi powszechny spis ludności, pp. 28-29.

13. Compiled on the basis of le premier recensement général, p. 62; and Drugi powszechny spis ludności, pp. 28-29. 
Table 3. Farms Employing Wage Labor, Wolyń Województwo, 1931

\begin{tabular}{|c|c|c|c|c|c|}
\hline Powiat & Total & $\begin{array}{c}\text { Poor } \\
0-5 \text { hectares } \\
\text { (percent) }\end{array}$ & $\begin{array}{c}\text { Middle } \\
\text { 5-10 hectares } \\
\text { (percent) }\end{array}$ & $\begin{array}{c}\text { Rich } \\
10-50 \text { hectares } \\
\text { (percent) }\end{array}$ & $\begin{array}{c}50+ \\
\text { hectares \& } \\
\text { unknown } \\
\text { combined } \\
\text { (percent) }\end{array}$ \\
\hline Wlodzimierz & 1,112 & 16 & 31 & 36 & 17 \\
\hline Dubno & 2,046 & 17 & 29 & 37 & 17 \\
\hline Horochów & 1,018 & 17 & 32 & 37 & 13 \\
\hline Łuck & 2,718 & 18 & 36 & 33 & 13 \\
\hline Równe & 1,874 & 22 & 32 & 36 & 10 \\
\hline Zdolbunów & 712 & 23 & 31 & 30 & 16 \\
\hline Krzemieniec & 990 & 24 & 20 & 34 & 22 \\
\hline Kowel & 1,520 & 25 & 31 & 25 & 19 \\
\hline Luboml & 468 & 26 & $\mathbf{a}$ & 22 & 19 \\
\hline Kostopol & 1,174 & 31 & 38 & 22 & 9 \\
\hline Sarny & 1,184 & 40 & 27 & 21 & 12 \\
\hline
\end{tabular}

a Data unavailable.

Source: Drugi porvszechny spis ludności $z$ dn. $9 . X I I 1931$ r., Województwo Wolyńskie, pp. 327-29.

The number of landholders who employed paid agricultural workers may be used as a rough index of the size of the agricultural wage-labor force in a given powiat. (The census provides no statistics on the number of wage laborers employed in agriculture.) The nationality of the owner (something that the census does provide) is unimportant, because he may be assumed to have hired the cheapest labor available, regardless of nationality. Table 3 shows the total number of such landholdings per poreriat and their breakdown by size. It is significant that the largest numbers of farms employing hired labor are found in Dubno, Kowel, Łuck, and Równe powiaty. As was already seen in table.1, Kowel and Euck were the strongest Communist powriaty. Dubno had a respectable level of KPZU activity, though hardly equal to that of Kowel or Luck. Only Równe powriat, apparently one of the KPZU's weak spots, does not meet the expectation that large numbers of landless laborers are found in KPZUinfluenced powiaty.

Independent landholdings, those farms that do not "employ hired labor," can also be classified according to the category of peasant who owned the holding-poor, middle, or rich. Table 4 provides the breakdown according to size and powiat of such Ukrainian-owned farms, and points to a startling conclusion: the powiaty with the largest proportions of poor peasants (Zdołbunów-77 percent, Krzemieniec-77 percent, Kostopol-72 percent, and Równe-70 percent) experienced the largest OUN and, conversely, the smallest KPZU presence. (The one exception-Sarny with 69 percent-had neither a large OUN nor a large KPZU presence.) Even more significant is that the Kowel porviat, a Communist stronghold, had the smallest proportion (53 percent) of poor peasants. On the other hand, four OUN-dominated porviaty-Kostopol, Krzemieniec, Równe, and Zdołbunów-were among the lowest in-percentages (either combined or separate) of middle and rich peasants, while the KPZU-dominated powiaty-Horochów, Kowel, Luboml, and Luck-were among those with the largest middle and rich peasant concentrations (either combined or separate). Łuck, however, is also an exception to the generalization concerning OUN powriaty (see figure 2, p. 420 , for a pictorial representation of these findings). 
Table 4. Ukrainian Landholdings, Wołyń Województwo, 1931

\begin{tabular}{lcccc}
\hline & $\begin{array}{c}\text { Poor } \\
\text { 0-5 hectares } \\
\text { (percent) }\end{array}$ & $\begin{array}{c}\text { Middle } \\
\text { 5-10 hectares } \\
\text { (percent) }\end{array}$ & $\begin{array}{c}\text { Rich } \\
\text { 10-50 hectares } \\
\text { (percent) }\end{array}$ & $\begin{array}{c}\text { Middlè/Rich } \\
\text { Combined } \\
\text { 5-50 hectares } \\
\text { (percent) }\end{array}$ \\
\hline Kowel & 53 & 38 & 11 & 49 \\
Włodzimierz & 55 & 39 & 8 & 47 \\
Horochów & 59 & 37 & 5 & 42 \\
Dubno & 61 & 34 & 6 & 40 \\
Euck & 62 & 33 & 6 & 39 \\
Lubom1 & 65 & 30 & 6 & 36 \\
Sarny & 69 & 25 & 7 & 32 \\
Równe & 70 & 26 & 4 & 30 \\
Kostopol & 72 & 24 & 5 & 29 \\
Krzemieniec & 77 & 21 & 3 & 24 \\
Zdołbunów & 77 & 21 & 2 & 23 \\
\hline
\end{tabular}

Source: Drugi powsaechny spis ludności z dn. $9 . X I I 1931$ r., Wojezództwo Wolyńskie, pp. $327-29$.

What is to account for the fact that Ukrainian Communists were strongest in areas with the largest numbers of landless laborers and middle and rich peasants, and that Ukrainian Nationalists did best where poor peasants were most numerous? Jeffrey Paige has pointed out that peasants whose relationship to the land they work is based on money are most "prone" to unrest and rebellion. They lack the security of owning a small plot of land and are highly vulnerable to the vagaries of the market because they have the most direct relationship to the market, in the form of wages. Therefore, in times of economic stress (a term that is applicable to Poland during the entire interwar period) the agricultural laborer is the first to experience severe hardships and, having little to lose through a strike or some similar adventure, he is most likely to engage in the sort of revolutionary activity that aims at overthrowing a system based on private property. The Communist claim that private property was the source of the landless laborer's troubles was tailor-made for acquiring that laborer's support.

Middle and rich peasants, however, would not have supported the Ukrainian Communists for the same reason that the landless laborers rallied to the KPZU. A party that is committed to dispossessing a certain group of people is obviously unlikely to win their support. But in that case, how can one account for the large middle and rich peasant presence in KPZU powiaty? Where there are many landless laborers there are likely to be many landholding peasants with more land than they and their families alone can work and who therefore require the assistance of hired labor. As table 3 shows, middle and rich peasants claimed the largest percentage of farms employing wage labor. At the same time, both were in the minority of every powiat's peasant population (see table 4 ). The size of an agricultural wage-labor force was, therefore, very dependent on the available number of middle and rich peasant farms. Consequently, it is not surprising that the powiaty with the largest numbers of agricultural laborers (Dubno, Kowel, Luck) also had very large numbers of middle and rich peasants (except Równe powriat). 
Figure 2. Powiaty with the Most Landless Laborers, Poor Peasants, and Combined Middle/Rich Peasants, Wotyń Województwo, circa 1930

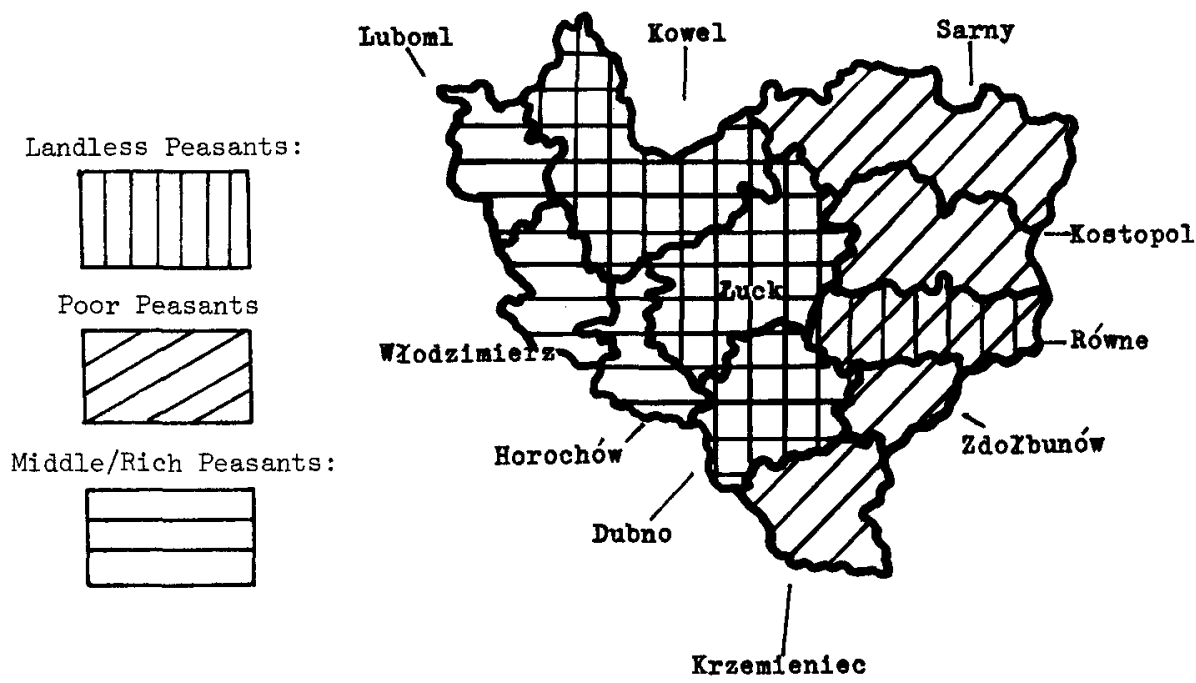

Despite its interest in maintaining stability, the middle and rich peasantry was unlikely to give its support to the OUN because the Nationalists, although favoring private landholdings, saw revolution as the only means of correcting the injustices inherent in the existing order. Nationalistically oriented political parties, such as the Ukrainian National Democratic Union (UNDO)-which worked within the Polish parliamentary system and practiced an evolutionary form of politics-provided better representation for the interests of the more prosperous Ukrainian peasantry. Poor peasants, on the other hand, were precisely the group to find the OUN's politics most attractive. Much more than middle or rich peasants, poor peasants were driven by the Depression into a position of extreme economic marginality. Not quite able to survive on their tiny plots and increasingly receptive to radical solutions which promised to increase the size of their holdings, poor peasants viewed the OUN's call to revolution as an answer to their economic ills. Like the agricultural laborers, poor peasants desired radical transformation of the existing social relationships. Unlike the landless laborers, however, poor peasants placed great value on ownership of land.

The hypotheses presented here can only be fully corroborated by similar studies dealing with the other Ukrainian-populated województwa of Poland, as well as by possible cross-cultural comparisons. As a result, these findings are necessarily more suggestive than conclusive. They are not intended as statements of absolute fact, but may, perhaps, - serve as a stimulus to further research in this sadly neglected area of Ukrainian studies. 